\title{
The Teaching Effect Investigation and Improvement Suggestion of SCM Sand Table Training Course
}

\author{
Bo WANG* \\ Management Department \\ The Engineering \&Technical College of Chengdu University of Technology \\ Leshan City, Sichuan Province, China \\ e-mail: wangbo41@126.com
}

\begin{abstract}
In order to improve te aching effect of supply chain management (SCM) sand table training course, and make sand table courses can play a better role in improving students' comprehensive practical ability, this article mainly put forward some teaching reform ideas. It is based on the teaching practice of SCM sand table course in the Engineering \& Technology College of Chengdu University of Technology. A questionnaire survey was conducted on the teaching method and effect of this course. The results show that: the difficulty and the present teaching design of SCM sand table course is relatively suitable and reasonable. However, there is still room for further improvement on courses, including grouping method, the advance distribution and explanation of course materials (rules), pre class planning, course schedule, course assessment and so on.
\end{abstract}

Keywords-SCM sand table course; teaching effect; practical training; questionnaire

\section{INTRODUCTION}

Sand table simulation of supply chain management (SCM) is a practical training course opened in domestic economy management specialty in order to improve students' management decision ability and supply chain collaboration skills after ERP sand table simulation of enterprise management [1]. The SCM sand table adopts traditional way of sand table group role confrontation. With sand table props, let the students deeply understand the advanced management concept of supply chain management through actual operation of supply chain basic operation content, operation skills and related basic knowledge. It contains zero inventory, risk management, marketing management, and financial management, scale management, planning management, product development, win-win cooperation and other modern management ideas, which are needed by enterprises and should be possessed by modern managers [2]. Concretely speaking, the SCM sand table comprehensively simulates the business activities of manufacturers, channels and terminal vendors in a supply chain in the real business environment. In practical training, a supply chain consists of three node enterprises (manufacturer, channel, and terminal). Students feel the competition and cooperation between upstream and downstream enterprises of supply chain in the fierce confrontation of sand table operation, look for the balance of Win-Win in supply chain, and then they can think about the operation strategy of the enterprise from the angle of the whole supply chain, that how to realize the maximization of

This work was supported financially by teaching research and education reform project of Engineering \&Technical College of Chengdu University of Technology(2016-YY-JG40)
Enterprise benefit under the premise of Co-existence of Enterprise in the chain[3].

\section{InVestigation Purpose And Questionnaire Design}

The SCM sand table is different from traditional ERP sand table. There's a fundamental difference in organization modern, ERP emphasizes the management and confrontation of manufacturing enterprises as the basic unit. While the SCM sand table breaks through the boundary of the enterprise. It asks that the operation of the enterprise must consider the operation condition of the upstream and downstream enterprises. The operation of logistics and information flow in the supply chain will have a direct impact on the operation of the enterprise on the chain. This simulated operation is closer to the real business environment, but it also adds exceptions to the teaching process, which brings more challenge to the teachers' teaching. According to the author's reference to relevant research, the existing research of this course tends to focus on the angle of teaching design, and mainly analyses according to teachers' subjective feelings, the real opinions of the students is rarely understood. The teaching practice of the author also shows that there are many problems in the course; therefore, this article adopts the method of questionnaire, which is to make a timely investigation to the students at the end of the course to understand the real opinions and feeling of the students, thus to improve the teaching effect of the sand table course.

The questionnaire investigates from grouping mode, the help of providing course training materials (rules) in advance to course learning, necessity of explaining rules in detail before formal training, course difficulty, views on the biggest problem of own simulated enterprise, the greatest gain of the course and its recommendations. The respondents are sophomore students whose major is industrial and commercial management in the College of Engineering and Technology in Chengdu University of Technology. There are 32 valid questionnaires.

\section{ANALYSIS OF INVESTIGATION RESULTS}

\section{A. The choice of grouping mode}

There are two modes to choice in the questionnaire, free combination and random combination (divided by teacher). The result shows that $81.3 \%$ students prefer to free combination, $15.6 \%$ students prefer to random combination, and one student didn't make any choice, he think that there is 
obvious shortage in free combination and random combination, and the third mode is needed, such as through a game that is welcomed by the students, and divide groups according to the final results of the game, please refer to table 1 for details.

TABLE I. PREFERRED GROUPING MODE

\begin{tabular}{|c|c|l|}
\hline $\begin{array}{c}\text { Grouping } \\
\text { mode }\end{array}$ & Percentage & \multicolumn{1}{c|}{ Main reason } \\
\hline $\begin{array}{c}\text { free } \\
\text { combination }\end{array}$ & $81.3 \%$ & $\begin{array}{l}\text { The team members have a high degree } \\
\text { of tacit agreement; similar to finding } \\
\text { partners in the society, it can give full } \\
\text { play to its advantages and enhance the } \\
\text { cohesion and cooperation of the team; it } \\
\text { can simulate their interest. }\end{array}$ \\
\hline $\begin{array}{c}\text { random } \\
\text { combination } \\
\text { (divided by } \\
\text { teacher) }\end{array}$ & $15.6 \%$ & $\begin{array}{l}\text { Grouping by roll call is fast; reduce the } \\
\text { time wasted by grouping; fair; get to } \\
\text { know mo re classmates, increase } \\
\text { friendships, and be more balanced than } \\
\text { free combination; to keep people from } \\
\text { alone. }\end{array}$ \\
\hline $\begin{array}{c}\text { Other modes } \\
\text { (such as } \\
\text { game result) }\end{array}$ & $3.1 \%$ & $\begin{array}{l}\text { Free combination will let good friends } \\
\text { together; there is big difference between } \\
\text { groups; random combination may have a } \\
\text { problem in communication, even } \\
\text { unhappy things may occur. }\end{array}$ \\
\hline
\end{tabular}

\section{B. Provide and explain course training materials (rules) in advance}

Because sand table of supply chain management relates to three different enterprises, besides public rules, it also relates to the respective rules of manufacturer, channel, and terminal. The calculation of advertisement benefit value is also very complicated. Although each student is responsible for only one simulation enterprise, however, the three enterprises are in one supply chain and closely related. It is necessary to know the operating rules of nodal enterprises. Based on it, the author investigated the opinion of students to whether it is helpful or not to provide course training materials (rules) in advance, and the necessity of explaining rules in detail before formal training. The result shows that most of (90.6\%) students think that it is helpful to provide course training materials (rules) in advance; most of $(84.4 \%)$ students think that it is necessary to explain rules in detail before formal training. Please refer to table 2 for details.

TABLE II. THE OPINION TO PROVIDING COURSE TRAINING MATERIALS (RULES) IN ADVANCE AND EXPLAINING RULES IN DET AIL

\begin{tabular}{|c|c|c|c|}
\hline $\begin{array}{c}\text { Providing training } \\
\text { rules in advance }\end{array}$ & Percentage & $\begin{array}{c}\text { Rule } \\
\text { explaining }\end{array}$ & Percentage \\
\hline helpful & $90.6 \%$ & Necessary & $84.4 \%$ \\
\hline Doesn't matter & $3.1 \%$ & Doesn't matter & $0 \%$ \\
\hline Not helpful & $6.3 \%$ & Not necessary & $15.6 \%$ \\
\hline
\end{tabular}

\section{Views on course difficulty}

According to the research, no one think that the course is too difficult, $40.6 \%$ of the students think that the course is a little bit difficult, $40.6 \%$ of the students think that the course is moderate difficulty, $15.6 \%$ of the students think that the curse is simple, $3.1 \%$ of the students think that the course is very simple.
Generally speaking, the difficulty of SCM sand table course is relatively reasonable. This is also consistent with 'the theory of the zone of proximal development". The zone of proximal development refers to the gap between the actual development level of students and the potential development level of students. Teaching should focus on the student's nearest development area, providing students with difficult content, mobilizing the enthusiasm of students and showing their potentials. The so-called "jump, pick the peach", the course content (target) must have some difficulty, need to jump up to achieve, but if it is too difficult, no matter how they jump, they still can't pick the peach, students will lose confidence. As a practical training course, the key of SCM sand table course is participation and thinking. Therefore, teachers should pay attention to the atmosphere of the course and open up the thinking of the students.

\section{Views on the biggest problem of own simulation enterprise}

From the feedback of the students, students think that the biggest problems of their simulation enterprises include the following aspects:

- No detailed and complete the planning before the training, many decisions is hasty and thoughtless.

- There is little communication between team members, especially in a supply chain, and teamwork is not enough, lack of tacit understanding.

- Unreasonable capital budgets, improper use of funds (such as advertising input).

\section{E. The greatest harvest of the course}

From the feedback of the students, through the learning of SCM sand table course, the students learned a lot, most of the students mentioned the following gains and promotion:

- Understand the importance of communication and teamwork, learn to cooperate and communicate, and enhance communication skills.

- Understand the basic principles and process of supply chain management.

- Understand the importance of overall planning and plan making, and consider the problem more comprehensively.

\section{F. Suggestions on course}

Students' suggestions on curriculum can be summarized as curriculum time, software design and instructional design:

- Time. It is suggested that the delay the overall training time, control the training time of each operation year and increase the number of trainings. Let the students know more about their roles and give them enough time to think.

- Software design. It is suggested that system should allow companies to trade, and suggests that the market competition of software to be more diversified.

- Teaching design. Reduce the number of groups, increase the number of members (as the number of the 
survey class is less, the majority of the group only assigned 5 members, the results show that many students suggest a group of 6 people); teachers should emphasize the supply chain node enterprises want to cooperate with each other; teachers should encourage students to think and do, do not fear of failure.

\section{Suggestions on Improving Teaching EfFeCt}

Besides the above mentioned grouping method, the advance distribution and explanation the course training rules, it puts forward some ideas and suggestions on teaching reform in the aspects of pre class planning, course schedule, course assessment and so on, in order to improve teaching effect.

- The sand table course of SCM is a kind of training course; the teacher should give students enough time to consideration and communication before the training and ask the team to submit the plan. There is an old saying "Preparedness ensures success, and unpreparedness spells failure”, teachers tell students to plan well before the rules are finished and the training is started, but there are always some students who are too lazy to think about it and start the training in a hurry. Therefore, the group can be required to submit the plan in advance to force the students to explore and think actively. The teachers can also point out the obvious defects in the program so that the students can correct the defects.

- In the process of the training, the progress of each group will be different, and such difference is caused by the failure of filling in and submitting the financial statements correctly after the end of each operation year. Together with fewer group members, some teams may feel incompetent, and the progress gap of experience is more obvious. In order to solve the problem, it is suggested that the teachers should lead the students to review the knowledge of financial statements before the training, so as to keep students from frittering away precious time and energy on non-essential in filling out financial statements and neglecting the participation and thinking of the curriculum itself.

- Because of the characteristics of SCM sand table course, students may take courses as games and not seriously consider the knowledge points contained in them. Therefore, in the process of practical training, teachers conclude the practical training through each stage, such as the competition and cooperation of the supply chain enterprises, the incentive of the core enterprises to the non-core enterprises, to help students gradually realize the necessity of carrying out the supply chain management in the modern market economy and how to effectively push it, so as to achieve the goal of experiential learning in "learning by doing, doing by learning'[4].

- Improve the course assessment mechanism. As SCM sand table course is antagonistic, some teachers tend to take the operation results of the enterprise as the only standard for the student performance assessment.
Actually, sand table curriculum is a kind of game, the confrontation results are uncertain because of the different decision, and the role of the students in the team is different because of the different roles played by the students. Students who study hard and participate actively do not necessarily win the confrontation. So it's obviously unfair to use confrontation results as the sole criterion of course assessment. It can be seen that it is very necessary to establish a complete course assessment mechanism[5]. Teachers should not only consider the results of confrontation, but also examine the students' course training reports. The course training reports can be evaluated according to the description of the training process, the analysis of the training problems and the summary of the experience. At the same time, it should also refer to the quantitative assessment of the students' overall performance in the course of the team operation.

\section{SUMMARY}

According to the questionnaire survey results, the difficulty and the present teaching design of SCM sand table course is relatively suitable and reasonable, but there is still room for further improvement on courses.

- It is advisable to adopt free combination in grouping, however, it also can be considered that let the group leader call group members together or use other assisting grouping mode.

- It is necessary to provide and explain course training materials (rules) in advance.

- It is necessary to establish a complete course assessment mechanism, and then make a comprehensive and fair comprehensive evaluation.

- Teachers should require students to submit group's training plan in advance to force them to explore and think actively.

- Teachers should lead the students to review the knowledge of financial statements before the training.

- Teachers should carry out specific training summary for each stage in the training process.

- Teachers could attempt to use "paid" mechanism for students' questions in the formal training, to improve competition antagonism and stimulate the students to learn independently.

\section{REFERENCES}

[1] Feng Junli. Supply Chain Management Sand Table Simulation Teaching Based on Course Teaching Life Cycle Theory. Monthly financial journal,2014,4(volume 2):125-128. (In Chinese)

[2] Wang Yanhong. The Function of Simulating Enterprise Supply Chain Management Sand Table Game to the Improvement of Practical Ability of Business Administration Major in two Colleges and Universities. Business , 2015 (6) :17. (In Chinese) 
[3] Li Jianjun. Research and Practice of Supply Chain Management Training Teaching System: a case study of the Project Prototype of School-Enterprise Cooperation "Supply Chain Management Sand Table Training". Examinations (Teaching and research edition), 2012 (11) :10-11. (In Chinese)

[4] iu Jing. Thinking on the Teaching of Supply Chain Management Sand Table Training Course in Higher Vocational Colleges. Jiannan literature, 2011 (8) :251-251. (In Chinese)

[5] Mu Zhuojun. Analysis of the Application of Sand Table Simulation in Supply Chain Management in Teaching. Contemporary economy, 2015 (4):96-97. (In Chinese) 